Jurnal Ekonomi dan Kebijakan

http://journal.unnes.ac.id/nju/index.php/jejak

\title{
Reducing Regional Poverty Rate in Central Java
}

\author{
Jaka Sriyana ${ }^{\bowtie}$ \\ Department of Economics, Univ ersitas Islam Indonesia, Yogyakarta \\ Permalink/DOI: https://doi.org/10.15294/jejak.v11i1.13272. \\ Received: October 2017; Accepted: January 2018; Published: March 2018
}

\begin{abstract}
This paper elaborates some appropriate policies regarding regional poverty reduction in Central Java province. This research estimates a poverty model based on a set of panel data comprising 29 regencies and six cities from 2011 to 2016 . A fixed-effect model presents that poverty rate has a negative association with regional economic growth, minimum wage level, number of unemployment, and the quality of human resources. The higher number of population significantly decreases poverty rate in each region. Also, this study indicates that there is more poverty rate in the eastern region than that in the west region. Moreover, the percentage of the poverty rate in regencies remains higher than the level in the cities. Overall, these results indicate that the local governments have successfully managed the poverty issues in among regencies and cities. This research finds that local governments are on the right way in their public policies in the development process. For more effective in poverty reduction, the local governments in the eastern region have to improve their human resources quality.
\end{abstract}

Key words : Poverty rate, Minimum wage, Unemployment, Education.

How to Cite : Sriyana, J. (2018). Reducing Regional Poverty Rate in Central Java. JEJAK: Jurnal Ekonomi dan Kebijakan, 11(1), 1-11. doi : https://doi.org/10.15294/jejak.v1111.13272 


\section{INTRODUCTION}

Poverty reduction is one of the major challenges in among regencies and cities in Indonesia (Miranti, Vidyattama, Hansnata, Cassells, \& Duncan, 2013). The process of poverty alleviation in the local economy needs the government involvement through some appropriate public policies. In recent years, local government programmes have to apply more proper and suitable programmes in their development process. Regarding poverty alleviation, it is important for the government to create a local economy that allows a low-income family to empower themselves. Since the poverty is the main problem in around regencies and cities in central Java, local government bureaucrats should encourage the community to involve in some poverty alleviation activities.

Some papers highlight that poverty has several dimensions aspects and causes (Chaudhry et al., 2009; Hanandita \& Tampubolon, 2016; Kis-Katos \& Sparrow, 2013; Miranti et al., 2013). Based on these research, the poverty may arise as consequences of economic and noneconomic turbulence.

In fact, non-income and income factors caused the phenomenon of poverty rising in among regencies and cities in Indonesia (KisKatos \& Sparrow 2013; Miranti et al. 2013). Moreover, poverty measurement may involve other dimensions rather than economic aspect.

The dimensions of human characteristics, education, working opportunity, ability accessing to basic infrastructure are considered as important factors of poverty (Chaudhry et al. 2009). Specifically, this paper mention that non-income factors such as education and environment of the low-income family are the most serious causes of poverty rate compared to other economic factors.
In contrast, other papers explain that economic factors, especially family income still play a most important role in classifying poverty (Duclos et al. 2006; Waglé 2008; Chaudhry et al. 2009). Net family income which indicates people capabilities plays as a main important instrument in the poverty rate. The debate of this issue leads some authors applying the new approach regarding the poverty reduction in some countries (Duclos et al. 2006; Qori'ah et al. 2010; Blank 2008; Abdelmawla 2014). Several recent papers provide some evidence of various poverty measurement which is very important for analyzing poverty issue in more varied perspectives. More complete indicators that involve the model then probably lead to more accurate results. As mentioned by recent papers that economic factors are an aspect to poverty, other dimensions such as public human resources quality, educational attainment, unemployment and spatial factors significantly affect poverty rate (Sobhan 2002; Vijayakumar \& Brezinova 2012; Sriyana 2015). This correlation emphasizes that analyzing poverty in other dimensions will provide more effective information to the poverty causes.

In recent years, the local governments in Indonesia have committed to arranging a longterm plan for some policies, regulations, and programme regarding poverty reduction (Hanandita \& Tampubolon 2016). However, many factors may affect local government capacity toward policy formulation regarding poverty reduction. Some papers stressed the role of government regulations to optimize local economic performances (Atkinson \& Bourguignon 1982; Kis-Katos \& Sparrow 2013; McCulloch et al. 2007; Hanandita \& Tampubolon 2016). Moreover, other papers mentioned that government regulation on fulfilling basic needs would improve low-income family capability (Duclos et al. 2006; Miranti et al. 2013; Afandi et al. 2017). 
The effectivity of poverty reduction depends on the quality of government bureaucrats, as well as the classification of local governmental namely regency and city in Indonesia.

Some empirical assessments of poverty alleviation which involves multi-dimension factors reveal that external aspects play more important effects in several countries (KisKatos \& Sparrow 2013; Kimura \& Silva 2017; Rustiadi \& Nasution 2017). Furthermore, an analysis to formulate appropriate and effective policies regarding poverty reduction must involve several multidimensional factors including internal and external variables. Some internal factors such as education attainment, working hour, and the total population in each region are the characteristics of the low-income family as important causes of regional poverty in some provinces in Indonesia including Central Java. Meanwhile, external factors such as government regulations, trade, ability to assess financial institution also play an important role in local governments. After determining some factors affecting poverty rate, local governments have the opportunity to develop more appropriate policies regarding poverty alleviation programmes (Alkire \& Foster 2008; Sobhan 2002; Hanandita \& Tampubolon 2016).

The Central Java province which is in the center of Java island consists of 29 regencies and six cities. This province has experienced with multidimensional aspects regarding poverty rate. The spatial location of regions, for example, might also affect the number of low-income families. For this reason, this research elaborates the location of regencies and cities using dummy variable in the model. This analysis also includes other dummy variable covering the different role of city and regency as determinants of the poverty rate. Regarding analyze the impact of government policy on poverty reduction, this research considers economic development and human resources factors as the determinant of the poverty level. The model also includes regional minimum wage as an indicator of local government regulations. Moreover, the model also considers some factors of human resources including some population, unemployment rate, and education level.

\section{RESEARCH METHODS}

This research analyzes poverty model using panel regression approach for the data of regencies and cities in Central Java province. This research considers the poverty rate model as a function of gross regional domestic product (GRDP), regional minimum wage (RMW), unemployment rate (UNEMP), number of population (POP), and literacy rate (EDUC). The theoretical model of poverty rate is as follows:

Povertyit $=\mathrm{f}$ (GRDPit, RMWit, UNEMPit, POPit, EDUCit)

This research analyzes an empirical poverty model in regencies and cities in Central Java province using a set of panel data for the annual period of 2011-2016. This research defines poverty rate as a percentage of some poor people to the total population. Gross regional domestic product (GRDP) is real annual output in constant price 2010.

Regional minimum wage (RMW) refers to annual provincial minimum wage. The data of population (POP) indicates the number of annual population. Unemployment rate (UNEMP) is the percentage of annual unemployment to the total population. Last, the variable of education (EDUC) is literacy rate. All the data is from the annual statistical report of Jawa Tengah (Central Java) province published 
by Statistics of Jawa Tengah Province (https://jateng.bps.go.id/).

As we stated before, this research applies regression analysis of panel data. The model provides more reliable estimates of the parameters and covers unobservable factors that vary across units and overtime of the data. The panel data regression is also able to identify and measure cross-sectional and time-series effects of data. Furthermore, the model can substantially reduce bias of the coefficient estimates. A panel data regression has lower multi co-linearity among its explanatory variables comparing to multiple equation regression.

We develop a panel regression model that involves a dependent variable of poverty rate and some observable explanatory variables as mentioned before for some units and annual period. These panel data consist of $\mathrm{N}$-units and T-time periods, and therefore the model has $\mathrm{N}$ times $\mathrm{T}$ observations. Then, the panel regression is as follows:

Povertyit $=\beta$ oit $+\beta_{1}$ GRDPit $+\beta_{2}$ RMWit + $\beta_{3}$ UNEMPit $+\beta_{4}$ POPit $+\beta_{5}$ EDUCit + $\mu$ it.

Where $: \mathrm{i}=1,2, \ldots, \mathrm{N}$ and $\mathrm{t}=1,2, \ldots, \mathrm{T}$

Povertyit is the value of poverty rate for the regency/city $i$ and the year $t$. The value of each explanatory variable is also for unit and period as well as the $\mu$ it that means the residual for the unit $i$ and the period $t$. Error term for the panel data regression model comprises two components that vary across units-over time and all unobserved factors as constant effects.

The first component leads to fixed effects model meanwhile the second component represents a random effects model.

It assumes that unobservable factors for the unit $i$ and period at $t$ may affect constant at the panel regression empirical models. As widely known, the three models of panel data analysis are common, fixed effects and random effects model. For this reason, a standard procedure of economic analysis using panel regression must select the best model. To find the best empirical model using panel data, several steps of testing procedure which involve Chow and Hausman test.

A common model (CE) assumes that a set of panel data has no effects both on units and time periods. There are no different intercepts for common model due to individual and timer period effects. In other words, the model is considered applicable for all individual observations or period data in the multiple linear regressions. Furthermore, this model assumes that individual data across unit and time variant do not affect the coefficients estimate.

The other model, fixed effects model (FEM) assumes that differences in the constant term capture unobservable factors across units and period of observation are. In this model, the estimate empirical model has different intercepts as a result of different units and time periods. A different important assumption in the third model, namely random effects model (REM) is that the unobserved random effects are uncorrelated with the independent variables. These factors affect the intercept values for each unit and period through residual as random effects. A REM is usually preferable in economic analysis because of its ability to cover unobservable characteristics of the data based on the difference cross unit and period through random effects in its error term.

Model selection among these three approaches will be conducted using redundant fixed effect test (Chow test) as a prerequisite first step and correlated random effects test (Hausman test). The first criterion test is used to select which a better model between CE and FEM is. Another second testing procedure is used to 
compare REM against FEM. Finally, the presentation and discussion of this poverty analysis use the best empirical model.

\section{RESULTS AND DISCUSSION}

All regencies and cities in Central Java province have been a remarkable success in reducing poverty since the 2010 s which is indicated by decreasing of poverty rate (Figure 1). The declining of the poverty rate in this province indicates that local governments have successfully reduced the number of poor people through several development programmes. The behavior of poverty rate based on regency and city may be different across time. Meanwhile, Table 1 presents descriptive statistical indicators of the variables. Figure 1 describes the behavior of annual poverty rate for 35 regions which are indicated using subscript 1-35 for each regency/city respectively. Based on these data, all regencies and cities experienced successfully with reducing poverty rate for this period.
As mentioned in the previous section, a panel regression consists of empirical models, namely common model, fixed effects model, and random effects model. The analysis should follow two steps testing procedure to find the best model, Chow and Hausman test. Three empirical models confirm that all independent variables are individually significant (Table 2 ). All empirical models result in a high coefficient of determination which indicates that estimation procedure is valid.

The result of Chow test between common and fixed effects using $F$ statistic give the insignificant result. It means that fixed effects model is better than the common model. The next step is to assess fixed effects and random effects model using Hausman procedure.

The probability value of chi-square statistic is o.oo1; it indicates that fixed effects model is more acceptable than other models. Further discussion of empirical poverty model will refer to fixed effects model.

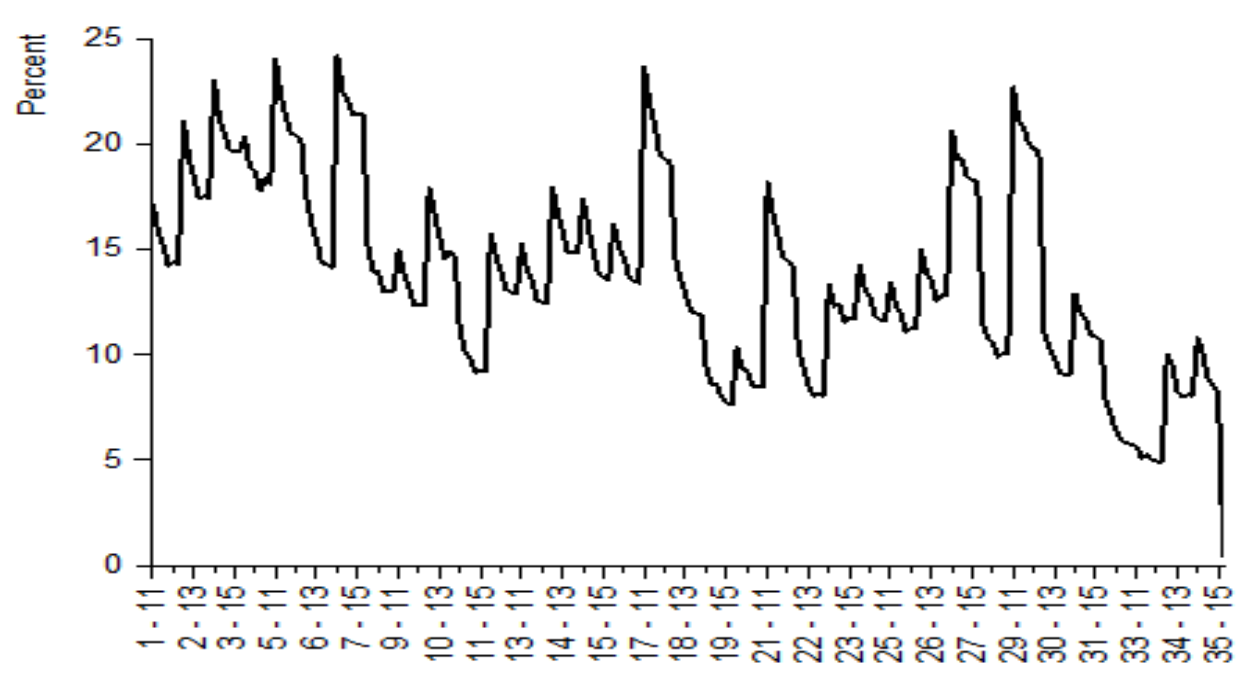

Figure 1. Poverty rate across cities and regencies (\%)

Note: The vertical axis is the poverty rate meanwhile the horizontal axis indicates the local government at the certain year. 1=Cilacap, 2=Banyumas, $\quad 3=$ =Purbalingga, 
4=Banjarnegara, 5=Kebumen, 6=Purworejo, 7=Wonosobo, 8=Magelang, 9=Boyolali, 10=Klaten, $\quad 11=$ Sukoharjo, $\quad 12=$ Wonogiri, 13=Karanganyar, 14=Sragen, 15=Grobogan, 16=Blora, 17=Rembang, 18=Pati, 19=Kudus, $\mathbf{2 0}=$ Jepara $\quad 2 \mathbf{2 1}=$ Demak, $\quad \mathbf{2 2}=$ Semarang, 23=Temanggung, 24=Kendal, 25=Batang, 26=Pekalongan, 27=Pemalang, 28=Tegal, 29=Brebes, 30=Kota Magelang, 31=Kota Surakarta, 32=Kota Salatiga, 33=Kota Semarang, 34=Kota Pekalongan, 35=Kota Tegal. The Number 1-27 are regencies; Number 30-35 are cities.

The fixed effects model presented in Table 2 involves five independent variables namely, gross regional domestic product, regional minimum wage, unemployment rate, number of population and education participation rate. As theoretically expected, three independent variables namely gross regional domestic product, regional minimum wage, and education participation rate are negatively significant. Meanwhile, unemployment has a positive correlation with poverty rate. The variable of the population is negative statistically significant indicating population number caused poverty rate. It implies that the increase of higher quality of population will contribute reducing poor people.

In this model, a gross regional domestic product which represents real income has a negative correlation with poverty rate. This finding is in line with the economic theory that economic growth leads to reduce the number of poor people. This paper emphasizes that income variable is the main aspect in determining poverty rate in central Java. It also may be inferred economic growth plays the very important role of in alleviating poor people number.

In this empirical model, unemployment variable has a positive correlation with poverty rate. As economic theory explains, unemployment can contribute to the decreasing social welfare which leads to increasing poverty rate. High unemployment in a country will reduce the welfare rate of the society. Based on this results, this finding is not debatable (Chaudhry et al. 2009; Sriyana 2015). However, this research supports the proposition the strong relationship between unemployment and poverty. Unemployment rate significantly causes poverty rate increase in the regions.

Table 1. Decriptive Statistic of Variables, 2011-2 016

\begin{tabular}{lllllll}
\hline & $\begin{array}{l}\text { Poverty } \\
\text { Rate (\%) }\end{array}$ & $\begin{array}{l}\text { GRDP } \\
\text { (Trillion Rp) }\end{array}$ & $\begin{array}{l}\text { RM) } \\
\text { (Thousand }\end{array}$ & $\begin{array}{l}\text { UNEMP } \\
(\%)\end{array}$ & $\begin{array}{l}\text { POP } \\
\text { (Person) }\end{array}$ & $\begin{array}{l}\text { EDUC } \\
(\%)\end{array}$ \\
\hline Mean & 13.98 & 19.65 & 967.34 & 5.89 & 947.19 & 92.39 \\
Median & 13.66 & 13.89 & 908.00 & 5.65 & 895.98 & 92.79 \\
Maximum & 24.21 & 102.50 & $1,685.00$. & 11.98 & $1,781.00$ & 98.30 \\
Minimum & 4.97 & 4.01 & 717.00 & 1.50 & 117.91 & 82.42 \\
Observation & 210 & 210 & 210 & 210 & 210 & 210 \\
\hline
\end{tabular}

Finally, this research provides a positive impact on local government regulation and poverty reduction. It also indicates that the local government policies contribute to the better quality of life at the local level. This result suggests that local government should 
create more regulation relating to the human quality improvement.

Table 3 presents the models involve dummy variable (D1) as an attribute of western and eastern regencies and cities. We classify the eastern twenty regions $\left(D_{1}=1\right)$ and other western regions $\left(D_{1}=0\right)$. This result confirms the proposition of spatial unbalance poverty among regencies and cities in Central Java (Model 1). The second dummy variable indicates the regency $\left(D_{2}=1\right)$ and the city $\left(\mathrm{D}_{2}=0\right)$. The empirical model presented by Model 2 informs that this variable is not significant. We infer that among regencies do not have higher poverty rate than that in the cities in this province. Moreover, unbalance development accrued as an impact of the position between western and eastern regions. This research may conclude that location has a significant role in the poverty rate as a result of the development process at the local level (Kalenkoski \& Lacombe 2008; Hanandita \& Tampubolon 2016). Some possible factors including the quality of infrastructure, public facilities, and other social and economic factors may cause why eastern regencies and cities experienced more poor people than that in western regions.

As an important point regarding with this poverty analysis, we estimate the empirical model using two dummy variables of a spatial factor and governmental type. Our result mention that these two dummy variable are statistically significant affecting poverty rate (Model 3). Overall, this empirical model can explain the determinants of poverty rate across regions in this province. The poverty levels both in regencies and cities are determined by some economic, education, and other social factors but also it is specified by spatial and governmental factors. The estimation result indicates that the eastern regencies have higher poverty rate in among local governments. Meanwhile, also referring to this estimation, some western cities have experienced the most successful in reducing their poverty rate comparing to other local governments.

Table 2. Estimates Result of Common, Fixed Effects, and Random Effects Model

\begin{tabular}{|c|c|c|c|c|c|c|}
\hline \multirow{2}{*}{$\begin{array}{l}\text { Independent } \\
\text { Variables }\end{array}$} & \multicolumn{2}{|c|}{ Common Model } & \multicolumn{2}{|c|}{ Fixed Effects Model } & \multicolumn{2}{|c|}{ Random Effects Model } \\
\hline & Coefficient & t-statistic & Coefficient & t-statistic & Coefficient & t-statistic \\
\hline Constant & 33.10 & $3.98 * * *$ & 40.12 & $6.19 * * *$ & 40.12 & $6.18 * * *$ \\
\hline GRDP & -0.10 & $-5.22 * * *$ & -0.11 & $-2.08 * *$ & -0.10 & $-2.07 * *$ \\
\hline RMW & -0.0072 & $-4.29 * * *$ & -0.003 & $-5.78 * * *$ & -0.003 & $-5.78 * * *$ \\
\hline UNEMP & -0.29 & $-1.95 * *$ & 0.16 & $3.44 * * *$ & 0.16 & $3.44 * * *$ \\
\hline POP & 0.005 & $6.31 * * *$ & -0.002 & $-2.10 * *$ & -0.002 & $-2.10 * *$ \\
\hline EDUC & -0.15 & -1.60 & -0.12 & $-2.55 * *$ & -0.12 & $-2.55 * *$ \\
\hline Adjusted $\mathrm{R}^{2}$ & \multicolumn{2}{|c|}{0.42} & \multicolumn{2}{|c|}{0.98} & \multicolumn{2}{|c|}{0.95} \\
\hline
\end{tabular}

Note: $* * *, * *=$ significant at 0.01 and 0.05 significance level respectively

The Role of Human Resources Development on Poverty Reduction for more sophisticated analysis.
We elaborate the causes of unbalance spatial poverty using response dummy variable. 
Table 3. Estimates Fixed Effects Models with Dummy Variables

\begin{tabular}{lcccccc}
\hline Independent & Model 1 & \multicolumn{3}{c}{ Model 2 } & \multicolumn{3}{c}{ Model 3 } \\
\cline { 2 - 7 } Variables & Coefficient & t-statistic & Coefficient & t-statistic & Coefficient & t-statistic \\
\hline Constant & 41.82 & $6.41^{* * *}$ & 34.82 & $3.82^{* * *}$ & 26.06 & $2.75^{* *}$ \\
GRDP & 0.128 & $2.43^{* *}$ & -0.06 & $-3.29^{* * *}$ & -0.09 & $-4.24^{* * *}$ \\
RMW & 0.17 & $3.70^{* * *}$ & -0.002 & $-4.79^{* * *}$ & -0.001 & $-2.85^{* * *}$ \\
UNEMP & -0.002 & $-2.54^{* *}$ & -0.16 & -0.94 & -0.06 & -0.37 \\
POP & -0.004 & $-5.71^{* * *}$ & 0.004 & $4.75^{* * *}$ & 0.005 & $5.36^{* * *}$ \\
EDUC & -0.11 & $-2.33^{* *}$ & -0.07 & -0.78 & -0.02 & -0.27 \\
D1 & 1.23 & $1.66^{*}$ & - & - & 2.10 & $2.77^{* * *}$ \\
D2 & - & - & 1.20 & 1.38 & 0.09 & $0.09^{*}$ \\
Adjusted R & 0.99 & & 0.49 & & 0.47 & \\
\hline
\end{tabular}

Note: ${ }^{* *},{ }^{* *},{ }^{*}=$ significant at $0.01,0.05$, and 0.10 significance level respectively

This variable is multiplication between Di and each independent variables. Table 4 presents the estimation results of three empirical models which involve dummy variable. We infer that number of population and lower education caused higher poverty in the eastern region. In another point of view, human resource development including education development and population growth are the key factors in poverty reduction in this region (Hanandita \& Tampubolon 2016).

Some important key factors regarding poverty reduction relate to human resources and community empowerment programmes. Since the decentralization era, local governments in Indonesia have more opportunity to plan their development programmes.

Based on some characteristics and the nature of poverty rate in regencies and city, the local government should deliver more appropriate action which has a significant impact on fighting poverty number. Following the decentralization framework, the local bureaucrats may use their potential chances to formulate some regulations (Miranti et al. 2013). Furthermore, the local governments should improve their policies management towards poverty reduction. Local governments should optimize the benefits from their power to encourage the people in improving their social welfare through some community development programmes. In this decentralization era, the regencies and cities governments have high opportunity to plan and organize their poverty elimination programmes across regions.

An important point of this research, about poverty elimination, the government programmes that consider economic, social, and spatial indicators can reduce region poverty rate in the province. We infer that more quality regulations and better human resources quality will cause more effective in reducing poverty. This research recommends the local governments supporting local economic structural transformation in eastern region through bottom-up community development programmes rather than top-down policies. 
Table 4. Estimates Results with Response Dummy Variables

\begin{tabular}{|c|c|c|c|c|c|}
\hline \multirow{4}{*}{$\begin{array}{l}\text { Independent } \\
\text { Variables }\end{array}$} & \multicolumn{5}{|c|}{ Fixed Effects Models } \\
\hline & Model & Model & Model & Model & Model \\
\hline & includes & includes & includes & includes & includes \\
\hline & $\mathrm{D}^{*}{ }^{*} \mathrm{GRDP}$ & $\mathrm{D}^{*}{ }^{*} \mathrm{MW}$ & D1*UNEMP & $\mathrm{D}_{1}^{*} \mathrm{POP}$ & D1*EDUC \\
\hline \multirow[t]{2}{*}{ Constant } & 26.98 & 30.04 & 26.18 & 21.54 & $9 \cdot 77$ \\
\hline & {$[2.86]^{* * *}$} & {$[3.13]^{* * *}$} & {$[2.81]^{* * *}$} & {$[2.35]^{* *}$} & [0.93] \\
\hline \multirow[t]{2}{*}{ GRDP } & -0.09 & -0.09 & -0.09 & -0.09 & -0.08 \\
\hline & {$[-4.19]^{* * *}$} & {$[-4 \cdot 33]^{* * *}$} & {$[-4 \cdot 45]^{* * *}$} & {$[-4.43]^{* * *}$} & {$[-3 \cdot 62]^{* * *}$} \\
\hline \multirow[t]{2}{*}{ RMW } & 0.004 & 0.005 & 0.005 & 0.002 & 0.003 \\
\hline & {$[-2.86]^{* * *}$} & {$[-3.19]^{* * *}$} & {$[-2.78]^{* * *}$} & {$[-3 \cdot 52]^{* * *}$} & {$[-2.33]^{* *}$} \\
\hline \multirow[t]{2}{*}{ UNEMP } & -0.001 & -0.002 & -0.001 & -0.001 & -0.009 \\
\hline & {$[-0.33]$} & {$[-0.32]$} & {$[-0.52]$} & {$[-0.05]$} & {$[-0.84]$} \\
\hline \multirow[t]{2}{*}{ POP } & -0.05 & -0.05 & -0.12 & -0.009 & -0.13 \\
\hline & {$[5.61]^{* * *}$} & {$[5 \cdot 79]^{* * *}$} & {$[5 \cdot 91]^{* * *}$} & {$[1.29]$} & {$[3 \cdot 37]^{* * *}$} \\
\hline \multirow[t]{2}{*}{ EDUC } & -0.02 & -0.025 & -0.024 & 0.08 & 0.15 \\
\hline & {$[-0.28]$} & {$[-0.23]$} & {$[-0.27]$} & {$[0.85]$} & {$[1.41]$} \\
\hline \multirow[t]{2}{*}{ D1 } & -2.38 & -6.42 & -2.71 & -6.83 & 56.12 \\
\hline & {$[-2.73]^{* * *}$} & {$[2.16]^{* *}$} & {$[-1.39]$} & {$[-4.06]^{* * *}$} & {$[3.04]^{* * *}$} \\
\hline \multirow[t]{2}{*}{$\mathrm{D}_{1}^{*} \mathrm{GRDP}$} & 0.013 & & & & \\
\hline & {$[0.45]$} & - & - & - & - \\
\hline \multirow[t]{2}{*}{$\mathrm{D} 1 * \mathrm{RMW}$} & & 0.004 & & & \\
\hline & - & {$[1.47]$} & - & - & - \\
\hline \multirow[t]{2}{*}{ Di*UNEMP } & & & 0.09 & & \\
\hline & - & - & {$[0.31]$} & - & - \\
\hline \multirow[t]{2}{*}{$\mathrm{D}_{1}^{*} \mathrm{POP}$} & & & & 0.005 & \\
\hline & - & - & - & {$[3.04]^{* * *}$} & - \\
\hline \multirow[t]{2}{*}{ D1*EDUC } & & & & & 0.63 \\
\hline & - & - & - & - & {$[3.16]^{* * *}$} \\
\hline Adjusted R2 & 0.49 & 0.50 & 0.49 & 0.52 & 0.52 \\
\hline
\end{tabular}

Note: Values in parentheses are t-statistic. ${ }^{* * *},{ }^{* *},{ }^{*}=$ significant at $0.01,0.05$, and 0.10 significance level respectively

Regarding poverty reduction at the local level, it requires an appropriate and effective plan, people participation, and community development programmes at the local economy. The regencies and cities governments in this province now should encourage poor people by providing resources to a poor people group, improving their education level, and supporting their real income to enable them to engage in the development process. 


\section{CONCLUSION}

This research provides the role of some government regulations to the poverty rate alleviation. The result presents some important factors such as economic and human resources as well as spatial as main indicators regarding the poverty alleviation in regencies and cities in Central Java province. Minimum wage policy has effectively reduced the poverty rate. Meanwhile, unemployment significantly increased the poor people number. At this point, economic aspect is the key factor to eliminate poverty level.

This research also highlights that local governments should improve the human resources quality through providing appropriate infrastructures in the education sector. These findings recommend the local bureaucrats emphasizing some programmes on poverty alleviation which meet poor people needs. Moreover, this research also reveals that the lower human resources quality in the eastern regencies are the key factors of the higher poverty rate in this region.

This research complement some previous findings that economic and human resources are most important indicators as the causes of poverty rate (Miranti et al. 2013; Rustiadi \& Nasution 2017; Hanandita \& Tampubolon 2016). Based on this reasons, this research recommends some key regulations might for policies planning related to poverty alleviation such as empowering low-income family through income generating programmes, improving poor people education level, reducing unemployment, ensuring control of wage level to ensure the accessibility of low-income family to various economic resources.

\section{RREFERENCES}

Abdelmawla, M.A., 2014. The Impacts of Zakat and Knowledge on Poverty Alleviation in Sudan: An Empirical Investigation (1990-2009). Journal of Economic Cooperation and Development, 35(4), pp.61-83.

Afandi, A., Wahyuni, D. \& Sriyana, J., 2017. Policies to Eliminate Poverty Rate in Indonesia. International Journal of Economics and Financial Issues, 7(1), pp.435-441.

Alkire, S. \& Foster, J., 2008. Counting and Multidimensional Poverty, United Kingdom: Queen Elizabeth House, University of Oxford.

Atkinson, A.B. \& Bourguignon, F., 1982. The Comparison of Multi-Dimensioned Distributions of Economic Status. Review of Economic Studies, 49, pp.183-201.

Blank, R.M., 2008. How to Improve Poverty Measurement in the United States. Journal of Policy Analysis and Management, 27(2), pp.233-254.

Chaudhry, I.S., Malik, S. \& Hassan, A., 2009. The Impact of Socioeconomic and Demographic Variables on Poverty: A Village Study. The Lahore Journal of Economics, 14(1), pp.39-68.

Duclos, J.Y., Sahn, D.E. \& Younger, S.D., 2006. Robust Multidimensional Poverty Comparisons. The Economic Journal, 116(514), pp.943-968.

Hanandita, W. \& Tampubolon, G., 2016. Multidimensional Poverty in Indonesia : Trend Over. Social Indicators Research, 128(2), pp.559-587.

Kalenkoski, C.M. \& Lacombe, D.J., 2008. Effects of minimum wages on youth employment: The importance of accounting for spatial correlation. Journal of Labor Research, 29, pp.303-317.

Kimura, F. \& Silva, M., 2017. Industrialization and poverty reduction in East Asia: Internal labor movements matter. Journal of Asian Economics, 48, pp.23-37. Available at: http://dx.doi.org/10.1016/j.asieco.2016.10.005.

Kis-Katos, K. \& Sparrow, R., 2013. Poverty, Labour Markets and Trade Liberalization in Indonesia. In The Institute for the Study of Labor Discussion Paper. pp. 1-32. Available at: http://www.econstor.eu/handle/10419/90005.

McCulloch, N., Weisbrod, J. \& Timmer, C.P., 2007. Pathways Out of Poverty During an Economic Crisis: an Empirical Assessment of Rural Indonesia. In Center for Global Development Working Paper. pp. 1-40. Available at: www.cgdev.org. 
Miranti, R. et al., 2013. Trends in Poverty and Inequality in Decentralising Indonesia. In OECD Social, Employment and Migration Working Papers. OECD Publishing., pp. 1-115. Available at: Http://dx.doi.org/.

Qori'ah, C.G., Indrawati, Y. \& Wardhono, A., 2010. Review of Policy on Poverty Elimination Programme. In The 1oth Indonesia Regional Science Association (IRSA) Conference. Surabaya, Indonesia, pp. 28-29.

Rustiadi, E. \& Nasution, A., 2017. Can Social Capital Investment Reduce Poverty in Rural Indonesia? International Journal of Economics and Financial Issues, 7(2), pp.109-117.

Sobhan, R., 2002. Mainstreaming Poverty Eradiction: Moving from Micro to Macro Agenda. In Centre for Policy Dialogue. Dhaka, Bangladesh, pp. 1-24.

Sriyana, J., 2015. Fiscal Capacity and Poverty Alleviation : A Panel Data Analysis for Yogyakarta Special Province. Jurnal Ekonomi Pembangunan, 16(1), pp.1-10.

Vijayakumar, S. \& Brezinova, O., 2012. Poverty Incidence and its Determinants in the Estate Sector of Sri Lanka. Journal of Competitiveness, 4(1), pp.4455 .

Waglé, U.R., 2008. Multidimensional poverty: An Alternative Measurement Approach for the United States? Social Science Research, 37(2), pp. 559-580. 